Trinity University

Digital Commons @ Trinity

Health Care Administration Faculty Research

Health Care Administration

$1-1999$

\title{
What Explains Wage Differences between Union Members and Covered Nonmembers?
}

Edward J. Schumacher

TrinityUniversity, eschumac@trinity.edu

Follow this and additional works at: https://digitalcommons.trinity.edu/hca_faculty

Part of the Health and Medical Administration Commons

\section{Repository Citation}

Schumacher, E.J. (1999). What explains wage differences between union members and covered nonmembers? Southern Economic Journal, 65(3), 493-512. doi: 10.2307/1060811

This Article is brought to you for free and open access by the Health Care Administration at Digital Commons @ Trinity. It has been accepted for inclusion in Health Care Administration Faculty Research by an authorized administrator of Digital Commons @ Trinity. For more information, please contact jcostanz@trinity.edu. 


\title{
What Explains Wage Differences Between Union Members and Covered Nonmembers?
}

\author{
Edward J. Schumacher*
}

\begin{abstract}
An individual covered by a collective bargaining agreement but who is not a union member is estimated to earn about $13 \%$ lower wages than a union member. Sectors with relatively few covered nonmembers are associated with a large coverage differential, while sectors with high proportions of covered nonmembers are associated with small differentials. This suggests freeriders either weaken the bargaining position of the union or weak bargaining positions increase the incentive to freeride. Only a modest amount of this differential is accounted for by unmeasured ability, the probationary period associated with newly hired union workers, or union status misclassification.
\end{abstract}

\section{Introduction}

Economists have devoted considerable attention to understanding the impact of unions on labor market outcomes, in particular to the estimation and interpretation of union/nonunion wage differentials. ${ }^{1}$ Less attention has been devoted, however, to the relevant measure of unionization. A worker can be covered by a collective bargaining agreement yet not be a member of the union. Lewis (1986) reviews previous studies examining the use of union membership or contract coverage as the appropriate measure of unionization and concludes that, while the use of membership yields a slightly higher coefficient estimate, the difference is small.

The primary piece of legislation concerning union security is the Taft-Hartley Act of 1947, which made closed shops illegal. ${ }^{2}$ In addition, Section 14 (b) of the act allowed states to make it illegal to require union membership or the payment of dues as a condition of continued employment. Thus, many states, primarily in the southeast and mountain regions, enacted rightto-work (RTW) laws. Workers in RTW states have the option of joining their union or not joining and remaining covered by the union contract. The union must equally represent all covered employees regardless of their membership status with respect to contract terms and representation in the grievance process. The National Labor Relations Act does not require employees covered by union security clauses to join a union or to support union activities beyond those relevant to collective bargaining, contract administration, and grievance adjustment (NLRB v. General Motors Corp. 373 U.S. 734, 1963). The covered nonmember, however, does not have the right to vote on union contracts or participate in other decision-making aspects of

\footnotetext{
* Department of Economics, East Carolina University, Greenville, NC 27858, USA; E-mail schumachere@mail.ecu.edu.

The author appreciates helpful suggestions from Marjorie Baldwin, John Budd, Barry Hirsch, Tom Mroz, Wayne Talley, and two anonymous referees. The Current Population Survey data sets used in this paper were developed with the assistance of David Macpherson and Barry Hirsch.

Received June 1997; accepted June 1998.

${ }^{1}$ See Lewis (1986) or Hirsch and Addison (1986) for a discussion of this literature.

${ }^{2}$ Exceptions were later made in the construction industry.
} 
the union. In non-right-to-work states, a new employee is required to join the union if there is a union security clause in place, typically before the end of an initial 90-day probationary period.

There has been considerable research on the determinants and effects of right-to-work laws (see, e.g., Farber 1984; Ellwood and Fine 1987; or see Moore and Newman [1985] and Moore [1998] for reviews of the literature). To the extent that covered nonmembers enjoy the same benefits of representation as members but with lower union dues, individuals have an incentive to freeride on the union contract. The more freeriders there are, however, the less effective the union will be and the benefits of unionization will be eroded. One strand of research in this area has focused on this freerider aspect of covered nonmembers (Booth 1985; Naylor 1989; Chaison and Dhavale 1992; Davis and Huston 1993; Naylor and Cripps 1993; Sobel 1995). Alternatively, others studies have attempted to estimate and interpret the wage differential between covered members and nonmembers referred to here as a membership differential or freerider penalty. Early studies using cross-sectional data typically found small significant differentials. For example, Jones (1982) uses data from the 1971 panels of the National Longitudinal Survey (NLS) and finds a membership differential of about $2 \%$ for young men and $3 \%$ for young women, with larger differentials for black men than white men and for white females than black females. Christensen and Maki (1983) find similar membership wage differentials.

More recent cross-sectional studies have found a larger membership wage differential. For example, Budd and $\mathrm{Na}$ (1997) find a membership premium of 11-14\% over covered nonmembers when using ordinary least squares (OLS) and larger estimates when using instrumental variable or sample selection methods. This differential is larger for men than women, but there are few differences across race and marital status, while the member differential varies substantially across occupational groups. Blakemore, Hunt, and Kiker (1986) and Hunt, Kiker, and Williams (1987) also find relatively large union membership differentials (about 13\%) over covered nonmembers.

A recent paper by Reilly (1996), however, using Canadian establishment-level data, finds little evidence for a membership differential. Once the union has organized more than $25 \%$ of the work force, there are significant establishment-wide effects on wages but no difference within establishments. Only for low union density establishments is the union able to capture a premium for members. These results suggest there is no establishment level freerider penalty.

This paper attempts to reconcile the seemingly conflicting findings between Reilly's conclusion that there is little evidence for a freerider penalty at the establishment level and those using nonestablishment cross-sectional data sets, which typically find significant freerider penalties. A common explanation consistent with both findings is provided. Evidence is first provided on the extent of the freerider penalty utilizing a large pooled time-series cross-sectional data set. Next, the paper examines the source of the differential. Freerider status appears to be correlated with the strength of the union. Consistent with the findings of Reilly (1996), when there are few freeriders in a particular occupation/industry sector, the union/nonunion differential is high, and when there is a high proportion of freeriders in a sector, there is only a small difference between union and nonunion wages. In addition, the impact of such factors as unmeasured ability, the probationary period of joining the union, and measurement error in the data are examined. None of these factors explains a sizable portion of the freerider penalty.

\section{Explaining the Membership Wage Differential}

Despite the legal requirement that union contracts equally represent members and nonmembers, cross-sectional data may reveal a wage difference between these workers. One pos- 
sible explanation is that freeriders proxy the strength of the union in a particular sector. Given the findings of Reilly (1996) that there is no freerider penalty at the establishment level, wage differentials across establishments must be capturing factors other than freeriding per se. Workers are more likely to join the union when the gains are high and have little incentive to join when benefits are low. Union membership in this case reflects stronger union wage effects in some bargaining units over others rather than a causal effect of membership on wages.

In addition to the union power hypothesis, there are other possible explanations for the freerider differential. There may be differences in ability, tastes, or motivation between members and freeriders not accounted for in micro level data sets. If workers with a stronger attachment to the job or who have higher (unmeasured) ability are more likely to join the union, then the freerider penalty will capture the lower ability of these individuals. Since the membership variable is capturing higher ability workers, statistical methods that better control for ability, motivation, and so forth should cause the freerider penalty to erode.

Second, the freerider penalty could be a result of the probationary period of initial union membership. In jobs with union shop contract clauses in non-RTW states, a newly hired worker is initially covered by the collective bargaining agreement but typically has a 90 -day probationary period. In RTW states, a newly hired employee need not join, but in either case, freeriding is more likely early in the stages of a new job and may be a proxy for job tenure, a wage determinant not included in standard cross-sectional studies (Reilly's analysis includes both experience and tenure). Thus, the union membership differential may be driven by a higher level of tenure on the job for union members over covered nonmembers.

The freerider penalty may also be due to a higher degree of misclassification in the data among covered nonmembers than members. The Current Population Survey (CPS) data used here are obtained from surveys, which first ask individuals if they are members of a labor union and, if not, asks if they are covered by a collective bargaining agreement. If individuals frequently report that they are covered nonmembers when in fact they are not covered, the data will reveal a wage differential for membership since this variable is a cleaner estimate of union representation.

\section{Estimating the Union Freerider Penalty}

\section{Measurement}

In order to examine the effects of union membership and contract coverage on wages, we start with a simple log wage equation of the form

$$
\ln W_{i}=X_{j i} \beta_{j}+\gamma \text { UNION }_{i}+e_{i},
$$

where $\ln W_{i}$ is the $\log$ real wage of worker $i$, vector $X$ consists of variables (indexed by $j$ ) measuring personal and job-related characteristics, and $\beta$ is the coefficient vector. UNION is a dummy variable indicating union status, which could be defined as either membership or coverage. The coefficient $\gamma$ measures the union wage differential under the assumption that union and nonunion wages differ only in the intercept term. For now, $e$ is assumed to be a wellbehaved error term. Alternatively, the model could be specified as

$$
\ln W_{i}=X_{j i} \beta_{j}+\delta C O V E R E D_{i}+\theta \text { FREERIDER } R_{i}+e_{i},
$$

where COVERED is a dummy variable equal to one if the individual is covered by a collective 
bargaining agreement and FREERIDER is equal to one if the individual is a covered nonmember. The coefficient estimate of $\delta$ provides a measure of the impact of contract coverage on wages, and $\theta$ provides a measure of the wage penalty associated with freeriding. Restricting the sample to those covered by a collective bargaining contract and including a single freerider dummy provides an estimate of the freerider differential without restricting the coefficient estimates on all the other right-hand side variables to be equal in and out of the union sector.

Due to potential unmeasured (to the researcher) ability correlated with union status, the union wage effects modeled above may be biased, so researchers have often utilized a fixed effects model to account for this (Freeman 1984; Jakubson 1991; Card 1996; Hirsch and Schumacher 1998). ${ }^{3}$ To illustrate, consider the following modification of Equation 2:

$$
\ln W_{i t}=X_{j i t} \beta_{j}+\delta C O V E R E D_{i t}+\theta F R E E R I D E R_{i t}+\Gamma_{i}+e_{i t}^{\prime}
$$

A time subscript $t$ is added, and the error term is decomposed into two components: an individual-specific component $(\Gamma)$ assumed fixed over time and a random, well-behaved component $\left(e^{\prime}\right)$. Estimates of $\theta$ are biased if $\Gamma$ is correlated with freerider status.

Letting $\Delta$ represent changes between adjacent years, a wage change equation takes the form

$$
\Delta \ln W_{d}=\Delta X_{j d} \beta_{j}+\delta \Delta C O V E R E D_{d}+\theta \Delta F R E E R I D E R_{d}+\Delta e_{d},
$$

where $d$ indexes the one-year time period over which changes are calculated. The fixed effect $\Gamma$ falls out, allowing unbiased estimates of the union coverage and membership effects. Jakubson (1991) shows that, when applied to union wage effects, the restriction implied in Equation 4 (a time-invariant fixed effect) is an appropriate specification of the more general form of the model, where $\Gamma$ is allowed to vary over time.

\section{Data}

Pooled time-series cross-sectional data for this study are drawn from the monthly CPS Outgoing Rotation Group (ORG) earnings files for January 1983 through October 1997. Beginning in 1983, union status questions were added to the earnings supplement, which are administered each month to a quarter sample (i.e., the outgoing rotation groups) of the CPS (monthly earnings supplements, absent the union status questions, began in January 1979). ${ }^{4}$ The data allow a distinction between members, freeriders (covered nonmembers), and noncovered workers. The survey first asks: "On this job, is . . a member of a labor union or an employee association similar to a union?" If individuals reply no, they are then asked: "On this job, is ... covered by a union or employee association contract?" Since the coverage question is not asked of individuals who indicate they are union members, we cannot identify the few workers who are members of a union but not covered by a collective bargaining agreement.

The sample consists of private-sector-employed wage and salary workers ages 18 or over whose major activity in the week prior to the survey was not schooling. ${ }^{5}$ In non-right-to-work states, there are relatively few covered nonmembers (according to the CPS data, $92.3 \%$ of those covered by a collective bargaining agreement are union members). Thus, the analysis is re-

\footnotetext{
${ }^{3}$ Others have utilized sample selection or instrumental variable methods (Lee 1978; Duncan and Leigh 1980; Robinson 1989a, b; Budd and Na 1997).

${ }^{4}$ Appendix 1 describes the construction of the data sets used in the paper.

${ }^{5}$ Hundley (1993) examines the public sector and finds a membership differential over covered nonmembers of about $5 \%$.
} 
Table 1. Union Density and Union Coverage and Freerider Wage Differentials: 1983-1997

\begin{tabular}{lccc}
\hline & All & White Collar & Blue Collar \\
\hline Density & & & \\
Coverage & 0.080 & 0.040 & 0.153 \\
Membership & 0.067 & 0.030 & 0.136 \\
Freeriders & 0.163 & 0.250 & 0.111 \\
Union Wage Differentials & & & \\
1. Coverage & 0.216 & 0.156 & 0.254 \\
& $(0.002)$ & $(0.003)$ & $(0.002)$ \\
2. Membership & 0.237 & 0.186 & 0.265 \\
& $(0.002)$ & $(0.004)$ & $(0.002)$ \\
3. Coverage & 0.240 & 0.188 & 0.269 \\
& $(0.002)$ & $(0.004)$ & $(0.002)$ \\
\multicolumn{1}{l}{ Freerider } & -0.140 & -0.120 & -0.129 \\
& $(0.005)$ & $(0.007)$ & $(0.006)$ \\
4. Freerider & -0.103 & -0.079 & -0.123 \\
& $(0.004)$ & $(0.007)$ & $(0.005)$ \\
Sample Size & 694,304 & 446,288 & 248,016 \\
\hline
\end{tabular}

Data are from CPS ORG files for January 1983 through October 1997; only right-to-work states are included. Standard errors are in parentheses. Blue collar jobs are defined as the following census occupational categories: farming, forestry, and fishing occupations; precision production, craft, and repair occupations; and operators, fabricators, and laborers. White collar jobs are defined as managerial and professional specialty occupations; technical, sales, and administrative support occupations; and service occupations. The union differentials are from a log wage equation. Line 1 includes a single dummy variable for coverage, and line 2 includes a single dummy variable for membership. Line 3 includes both coverage and freerider dummies, while in line 4, the sample is restricted to those covered by a collective bargaining agreement. The sample sizes for line 4 are 58,163, 18,936, and 39,227 for all, white collar, and blue collar, respectively. Other variables included in these regressions are potential experience and its square (interacted with gender), years of schooling, dummies for MSA size, gender, race (3), Hispanic status, marital status (2), part-time status, region (4), industry (12), occupation (5), and year (14). Full results are shown in Appendix 2.

stricted to right-to-work states where workers are free to choose whether or not to join. ${ }^{6}$ The wage is calculated as usual weekly earnings on the primary job (inclusive of tips, commissions, and overtime) divided by usual hours worked per week. For the small number of workers whose weekly earnings are top-coded (at \$999 through 1988 and \$1923 beginning in 1989), I assign the estimated mean earnings above the cap based on the assumption that the upper tail is characterized by a Pareto distribution. ${ }^{7}$ I omit from the sample workers with implicit hourly earnings of less than $\$ 1$ or more than $\$ 99.99$ October 1997 dollars.

\section{Union Density and Wage Differentials}

Table 1 displays pooled estimates of union density and union membership and coverage differentials. About $16 \%$ of those covered by a collective bargaining agreement are freeriders. This ratio is higher for white collar jobs than for blue collar jobs, while overall union density

\footnotetext{
${ }^{6}$ The following states had right-to-work laws in place over the sample period: Idaho, Wyoming, Iowa, Arizona, Utah, Nevada, North Dakota, South Dakota, Nebraska, Kansas, Arkansas, Louisiana, Texas, Tennessee, Alabama, Mississippi, Virginia, North Carolina, South Carolina, Georgia, and Florida. Idaho's RTW legislation was enacted in early 1985; all other states' laws were enacted before the sample period (most in the late 1940s or early 1950s).

${ }^{7}$ Means above the earnings cap are taken from Hirsch and Macpherson (1997, p. 6), who estimate annual gender-specific values from the Pareto distribution. Means in nominal dollars are roughly $\$ 1500$ for years with a $\$ 999$ cap and $\$ 3000$ for years with a $\$ 1923$ cap, with moderately higher values for men than women and increases in the means over time.
} 


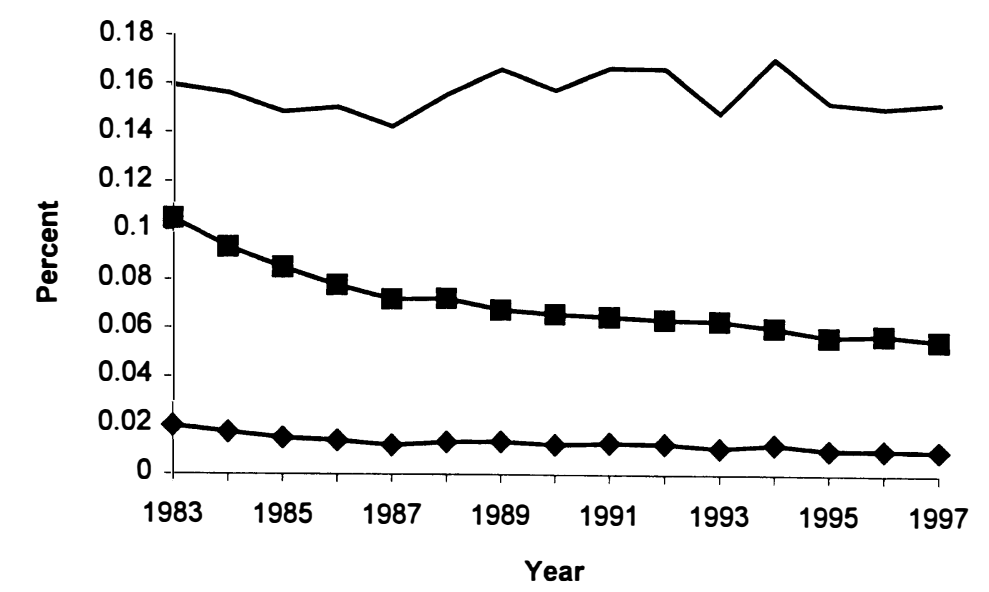

\section{- - Membership Density —Free-Rider Density —Free-Rider/Covered}

Figure 1. Data are from the January 1983 through October 1997 CPS ORG files. Shown are union coverage and freerider density and the percentage of those covered who are freeriders by year.

is higher for blue collar jobs. ${ }^{8}$ Lines 1 and 2 under the union wage differential provide estimates of Equation 1. Line 1 uses contract coverage and line 2 uses union membership. Variables included in these regressions were potential experience and its square (interacted with gender), years of schooling, dummies for metropolitan statistical area size, gender, race (3), Hispanic status, marital status (2), part-time status, region (4), industry (12), occupation (5), and year (14). Appendix 2 displays full regression results. The coefficient estimates are highly similar for both union status measures, with a slightly higher estimate $(0.24$ vs. 0.22$)$ when union membership is used. This is consistent with the conclusion of Lewis (1986) that the definition of union status is not an important distinction in estimating union wage effects. ${ }^{9}$

Since the coverage dummy compares those covered by a contract with those not covered and the membership dummy groups freeriders with nonunion workers, one might expect a larger coverage estimate since it is a cleaner measure of unionization. Table 1 suggests, if anything, the opposite is the case. Jones (1982) argues this is due to a high degree of misclassification among covered nonmembers. Using NLS data, she shows that freeriders are much more likely not to name their covering union, suggesting many of these workers are misclassified as covered rather than uncovered. This is examined further in section 5 below.

Line 3 of Table 1 provides estimates of $\delta$ and $\theta$ from Equation 2. Overall, there is a 27.4\% wage differential for union coverage. There is a substantial penalty, however, of $13.1 \%$ for freeriders. The union coverage differential is substantially higher in blue collar than white collar occupations (where union density is higher and freeriding is less frequent), yet the freerider penalties are similar. Line 4 restricts the sample to those covered by a collective bargaining agreement and includes a single dummy for freeriders. Freeriders receive about $7.5 \%$ lower

\footnotetext{
${ }^{8}$ Blue collar jobs are defined as the following census occupational categories: farming, forestry, and fishing occupations; precision production, craft, and repair occupations; and operators, fabricators, and laborers. White collar jobs are defined as managerial and professional specialty occupations; technical, sales, and administrative support occupations; and service occupations.

${ }_{9}^{9}$ The union wage differentials estimated here are slightly higher than standard estimates (Hirsch and Macpherson 1997, Table 2a) since the analysis is restricted to private sector workers in RTW states.
} 


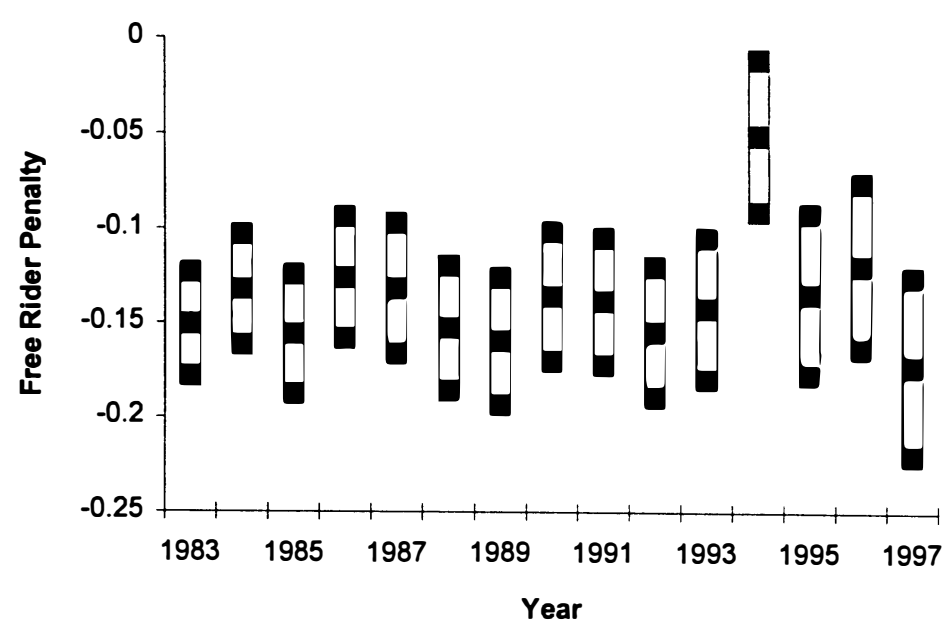

Figure 2. Data are from the January 1983 through October 1997 CPS ORG files. The figure shows the freerider differential estimated separately by year, with $95 \%$ confidence intervals.

wages in white collar jobs and $11.5 \%$ lower wages in blue collar jobs. Despite previous evidence that there is no differential when measured at the establishment level (Reilly 1996), pooled time-series cross-sectional data reveal a rather substantial differential. This suggests that, while the overall effect of unions on wages is not sensitive to whether membership or coverage is used (since there are relatively few freeriders), there are significant differences between union members and freeriders. ${ }^{10}$

The above regressions pooled the years 1983 through 1997. Union density was declining rather consistently over this period. Figure 1 displays union membership and freerider density as well as the freerider/coverage ratio from 1983 through 1997. The proportion of workers covered by a collective bargaining agreement (in right-to-work states) decreased throughout the period from a high of 0.10 in 1983 to a low of 0.05 in 1997. The decline appears to be steepest over the 1983 to 1987 period and levels off after that. The proportion of the workforce who are freeriders also declined over the period, although by less than the coverage proportion. The freerider to coverage ratio fluctuates around 0.16 with no clear trend over the period.

Figures 2 and 3 display freerider and coverage coefficients estimated separately by year. Figure 3 shows that, in RTW states, there has been a decline in the union coverage differential. ${ }^{11}$ In 1983, individuals covered by a collective bargaining agreement earned about $30 \%(0.26 \mathrm{log}$ points) higher wages than an equivalent worker not covered by a collective bargaining agreement. By 1997, this differential had fallen to about 23\% ( $0.20 \log$ points). Figure 2 shows, however, that the freerider penalty displayed little trend over the period. A test of the null

\footnotetext{
${ }^{10}$ Separate equations for union members, freeriders, and noncovered workers were also estimated. Conducting a Oaxaca/ Blinder decomposition using the nonunion means reveals that, of the unadjusted log wage differential of 0.356 between union members and noncovered workers, $0.167 \mathrm{log}$ points ( $47 \%$ of the unadjusted differential) is explained by differences in characteristics and $0.189 \mathrm{log}$ points (53\% of the unadjusted differential) is left unexplained. When using the union means, 0.245 is left unexplained. The unadjusted log wage differential between freeriders and union members is 0.161 ; of this, 0.064 (40\% of the unadjusted differential) is explained and $0.097(60 \%)$ is unexplained. When using the freerider means, 0.124 is left unexplained. These results indicate similar wage differentials as when estimating pooled equations. The remainder of the paper pools the groups since this greatly simplifies the presentation.

${ }^{11}$ The union wage differential for all states has remained fairly stable over this period (Blanchflower 1997, Hirsch and Macpherson 1997).
} 


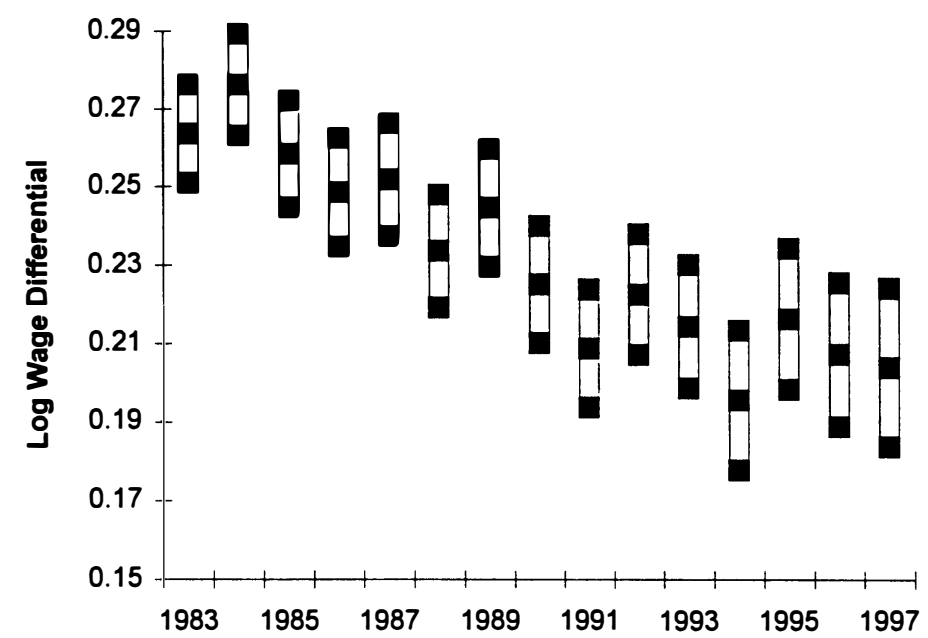

Figure 3. Data are from the January 1983 through October 1997 CPS ORG files. The figure shows the union coverage differential estimated separately by year, with $95 \%$ confidence intervals.

hypothesis that the coefficient on coverage is constant across the years reveals an $F$-statistic of 37.5 (assuming common coefficients for the other right-hand side variables). The equivalent test on the freerider dummy yields an $F$-value of 4.7 . Both of these tests are rejected at conventional critical values. ${ }^{12}$ The remainder of the paper includes both separate estimates of the coverage and freerider differentials by year as well as pooled estimates over the 1983-1997 period.

\section{Freeriders as a Proxy for Union Strength}

Table 1 and Figure 2 demonstrate that there is a rather substantial freerider penalty observed in cross-sectional data that appears to be robust over time and to model specification. Given Reilly's (1996) finding of no difference in earnings within establishments between members and nonmembers, what can explain this cross-sectional finding?

Unions provide benefits to workers in the form of higher wages and better information about the existence of workplace laws and rights created by those laws. This information is provided formally through educational programs, apprenticeship training, or provision of educational materials (Weil 1997). Unions also provide information on the existence of specific underlying problems, particularly in the areas of safety and health. When these wage and nonwage benefits are large, the worker will be more likely to join the union; when they are relatively small, many workers prefer not to pay dues and remain nonmembers.

The reasoning above implies that workers will be more closely affiliated with the union when the union is providing a higher level of benefits. Thus, the freerider penalty may capture differences in wages across collective bargaining contracts. If freeriding is associated with relatively low union wages, the union differential (as compared to nonunion workers) should be

\footnotetext{
${ }^{12} \mathrm{~A}$ formal test of the poolability of the data involves an extended version of the Chow test, which allows for $N$ linear regressions (Baltagi 1995). Assuming the error term in the individual regressions is $u \sim N\left(0, \sigma^{2} I_{N T}\right)$, the assumption of poolability is overwhelmingly rejected. My analysis indicates, however, that the conclusions of the paper are not sensitive to whether the data are pooled or not.
} 
higher when there are few freeriders. Since nonmembers erode the strength of the union, in sectors where there are few freeriders union strength should be high and the union wage differential should be high. To examine this, consider

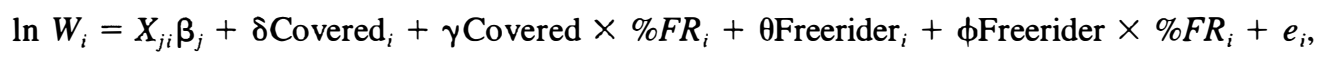

where $\% F R$ is the percentage of the worker's sector covered by collective bargaining agreements that are freeriders (calculated over six occupation by seven industry groups). If freeriding is associated with a weak union, the union/nonunion wage differential should be lower the higher the percentage of freeriders in the sector. Thus, the hypothesis is that the coefficient $\gamma$ should be negative. Note that the focus here is on how the coverage differential is affected by the extent of freeriding in the worker's sector. The hypothesis is that bargaining power for covered workers (members and freeriders) declines as freeridership increases.

Table 2 reveals that this is the case. ${ }^{13}$ The table shows the effects of interacting freerider density with union coverage and freeriding status. Focusing on the pooled results for ease of exposition, in a sector with the mean level of freeriding (0.246), union members earn wages about $0.17 \mathrm{log}$ points higher than nonunion workers $(0.349-[0.715 \times 0.246])$. As the percentage of freeriders in the workers' sector increases, the union coverage differential declines substantially. For example, a one standard deviation increase in freerider density results in an $8.2 \%$ decrease in the union coverage wage differential $(-715 \times 0.120)$. Consistent with the findings of Reilly (1996) that there is no freerider differential at the establishment level, these findings suggest that freeriding is correlated with weak union bargaining power and lower union earnings. Workers in unions with a high degree of membership earn higher wages, regardless of membership status. ${ }^{14}$

The coefficient on the interaction term between the freerider dummy and $\% F R$ is positive and significant, suggesting that the freerider penalty decreases with the percentage of freeriders in the sector. The literal interpretation of this coefficient would be that the ability of the union to "punish" freeriders decreases with the number of freeriders. If, however, the estimate is not capturing a freerider penalty per se but is a proxy for the strength of the union, there may be an alternative explanation for the positive coefficient on the interaction term. One possibility is that it is capturing variations in freerider density within occupation/industry cells. That is, the freerider dummy and corresponding interaction terms may be picking up unmeasured bargaining strength within sectors after accounting for some average measure of bargaining strength (\%FR).

To further test the idea that the freerider variable is a proxy for lower wage unions, we estimate equations that include separate coverage dummies for various industry, occupation, or region groups and include a single freerider dummy. The hypothesis is that the estimated freerider penalty should decline as more detailed controls for the coverage unit are included. Table 3 shows the effects on the membership differential of interacting the coverage dummy with different levels of industry and occupational dummies. The first column indicates that union

\footnotetext{
${ }^{13}$ The standard errors from coefficients involving $\% F R$ will be biased downward since many workers (observations) in a given market face the same freerider density, so their outcomes are not independent (Dickens and Ross 1984). The coefficient estimates, however, need not be biased.

${ }^{14}$ I also estimated the model by creating dummy variables for the four quartiles of freerider density (greater than 0.314 , 0.314 to $0.231,0.231$ to 0.124 , and less than 0.124 ) and interacted these with coverage and freerider. The results indicate that the union/nonunion wage differential declines with freerider density.
} 
Table 2. Freerider Density and Union Wage Differentials

\begin{tabular}{|c|c|c|c|c|c|c|}
\hline Year & Coverage & $\begin{array}{c}\text { Coverage } \\
\times \% F R\end{array}$ & Freerider & $\begin{array}{l}\text { Freerider } \\
\times \% \mathrm{FR}\end{array}$ & $\begin{array}{c}\text { Mean of } \\
\% F R\end{array}$ & $\begin{array}{c}\text { Standard } \\
\text { Deviation } \\
\text { of } \% F R\end{array}$ \\
\hline 1983-1997 & $\begin{array}{c}0.349 \\
(0.004)\end{array}$ & $\begin{array}{c}-0.715 \\
(0.022)\end{array}$ & $\begin{array}{c}-0.175 \\
(0.010)\end{array}$ & $\begin{array}{c}0.375 \\
(0.042)\end{array}$ & 0.246 & 0.120 \\
\hline 1983 & $\begin{array}{c}0.409 \\
(0.011)\end{array}$ & $\begin{array}{r}-0.779 \\
(0.064)\end{array}$ & $\begin{array}{c}-0.189 \\
(0.028)\end{array}$ & $\begin{array}{c}0.349 \\
(0.114)\end{array}$ & 0.254 & 0.145 \\
\hline 1984 & $\begin{array}{c}0.386 \\
(0.012)\end{array}$ & $\begin{array}{c}-0.618 \\
(0.071)\end{array}$ & $\begin{array}{c}-0.190 \\
(0.031)\end{array}$ & $\begin{array}{c}0.402 \\
(0.133)\end{array}$ & 0.248 & 0.149 \\
\hline 1985 & $\begin{array}{c}0.404 \\
(0.012)\end{array}$ & $\begin{array}{c}-0.859 \\
(0.075)\end{array}$ & $\begin{array}{c}-0.193 \\
(0.030)\end{array}$ & $\begin{array}{c}0.424 \\
(0.131)\end{array}$ & 0.236 & 0.148 \\
\hline 1986 & $\begin{array}{c}0.393 \\
(0.013)\end{array}$ & $\begin{array}{c}-0.831 \\
(0.076)\end{array}$ & $\begin{array}{c}-0.183 \\
(0.032)\end{array}$ & $\begin{array}{c}0.514 \\
(0.139)\end{array}$ & 0.237 & 0.144 \\
\hline 1987 & $\begin{array}{c}0.358 \\
(0.013)\end{array}$ & $\begin{array}{c}-0.677 \\
(0.084)\end{array}$ & $\begin{array}{c}-0.190 \\
(0.034)\end{array}$ & $\begin{array}{c}0.497 \\
(0.157)\end{array}$ & 0.213 & 0.122 \\
\hline 1988 & $\begin{array}{c}0.354 \\
(0.013)\end{array}$ & $\begin{array}{c}-0.701 \\
(0.076)\end{array}$ & $\begin{array}{c}-0.135 \\
(0.036)\end{array}$ & $\begin{array}{c}0.097 \\
(0.158)\end{array}$ & 0.242 & 0.130 \\
\hline 1989 & $\begin{array}{c}0.360 \\
(0.015)\end{array}$ & $\begin{array}{c}-0.672 \\
(0.083)\end{array}$ & $\begin{array}{c}-0.197 \\
(0.035)\end{array}$ & $\begin{array}{c}0.344 \\
(0.150)\end{array}$ & 0.260 & 0.141 \\
\hline 1990 & $\begin{array}{c}0.288 \\
(0.014)\end{array}$ & $\begin{array}{c}-0.410 \\
(0.084)\end{array}$ & $\begin{array}{c}-0.153 \\
(0.034)\end{array}$ & $\begin{array}{c}0.203 \\
(0.146)\end{array}$ & 0.241 & 0.129 \\
\hline 1991 & $\begin{array}{c}0.298 \\
(0.014)\end{array}$ & $\begin{array}{c}-0.593 \\
(0.079)\end{array}$ & $\begin{array}{c}-0.172 \\
(0.036)\end{array}$ & $\begin{array}{c}0.356 \\
(0.149)\end{array}$ & 0.253 & 0.131 \\
\hline 1992 & $\begin{array}{c}0.268 \\
(0.013)\end{array}$ & $\begin{array}{c}-0.367 \\
(0.068)\end{array}$ & $\begin{array}{c}-0.190 \\
(0.033)\end{array}$ & $\begin{array}{c}0.332 \\
(0.117)\end{array}$ & 0.289 & 0.170 \\
\hline 1993 & $\begin{array}{c}0.249 \\
(0.013)\end{array}$ & $\begin{array}{c}-0.392 \\
(0.082)\end{array}$ & $\begin{array}{c}-0.178 \\
(0.035)\end{array}$ & $\begin{array}{c}0.372 \\
(0.150)\end{array}$ & 0.246 & 0.148 \\
\hline 1994 & $\begin{array}{c}0.316 \\
(0.017)\end{array}$ & $\begin{array}{c}-0.798 \\
(0.097)\end{array}$ & $\begin{array}{c}-0.071 \\
(0.041)\end{array}$ & $\begin{array}{c}0.310 \\
(0.180)\end{array}$ & 0.236 & 0.110 \\
\hline 1995 & $\begin{array}{c}0.254 \\
(0.016)\end{array}$ & $\begin{array}{c}-0.430 \\
(0.096)\end{array}$ & $\begin{array}{c}-0.174 \\
(0.041)\end{array}$ & $\begin{array}{c}0.390 \\
(0.184)\end{array}$ & 0.229 & 0.127 \\
\hline 1996 & $\begin{array}{c}0.233 \\
(0.015)\end{array}$ & $\begin{array}{c}-0.279 \\
(0.090)\end{array}$ & $\begin{array}{c}-0.112 \\
(0.041)\end{array}$ & $\begin{array}{c}0.105 \\
(0.164)\end{array}$ & 0.232 & 0.140 \\
\hline 1997 & $\begin{array}{c}0.241 \\
(0.017)\end{array}$ & $\begin{array}{c}-0.350 \\
(0.100)\end{array}$ & $\begin{array}{c}-0.192 \\
(0.045)\end{array}$ & $\begin{array}{c}0.275 \\
(0.185)\end{array}$ & 0.242 & 0.142 \\
\hline
\end{tabular}

$\% F R$ is the ratio of freeriders to contract coverage calculated over six occupation and seven industry categories Standard errors are in parentheses. Other variables included in these regressions are potential experience and its square (interacted with gender), years of schooling, dummies for MSA size, gender, race (3), Hispanic status, marital status (2), part-time status, region (4), industry (12), occupation (5), and year (14) for the pooled regressions.

freeriders earn wages $-0.14 \log$ points lower than members when including only a single dummy for coverage. When interacting coverage with 45 occupational dummies (column 2), the freerider penalty falls to $-0.10 \mathrm{log}$ points. Similarly, if there are 42 occupation/industry groups ( 6 occupations by 7 industries), the differential falls to $-0.10 \log$ points. Columns 4,5 , and 6 indicate that, as the level of detail increases, the freerider penalty declines. For example, when including 156 separate coverage dummies (13 occupations by 12 industries), the estimate of the freerider penalty falls to -0.094 . When estimating separate equations by year, similar results are found. Thus, it appears that the freerider penalty is driven, at least in part, by differences in union wage effects across sectors. Reilly's findings for Canada suggest that the penalty also results from differences in union bargaining power across establishments within sectors. 
Table 3. Freerider Coefficient Estimates

\begin{tabular}{|c|c|c|c|c|c|c|}
\hline \multirow[b]{2}{*}{ Year } & \multicolumn{6}{|c|}{ Level of Sector Control } \\
\hline & $\begin{array}{l}\text { No Sector } \\
\text { Controls }\end{array}$ & 45 Occs & $\begin{array}{l}6 \text { Occ by } \\
7 \text { Ind }\end{array}$ & $\begin{array}{l}6 \text { Occ by } \\
12 \text { Ind }\end{array}$ & $\begin{array}{l}6 \text { Occ by } \\
12 \text { Ind by } \\
2 \text { Regions }\end{array}$ & $\begin{array}{l}13 \text { Occ by } \\
12 \text { Ind }\end{array}$ \\
\hline 1983-1997 & $\begin{array}{c}-0.140 \\
(0.005)\end{array}$ & $\begin{array}{c}-0.102 \\
(0.005)\end{array}$ & $\begin{array}{c}-0.102 \\
(0.005)\end{array}$ & $\begin{array}{c}-0.097 \\
(0.005)\end{array}$ & $\begin{array}{c}-0.097 \\
(0.005)\end{array}$ & $\begin{array}{r}-0.094 \\
(0.005)\end{array}$ \\
\hline 1983 & $\begin{array}{c}-0.151 \\
(0.014)\end{array}$ & $\begin{array}{c}-0.119 \\
(0.015)\end{array}$ & $\begin{array}{c}-0.112 \\
(0.015)\end{array}$ & $\begin{array}{c}-0.104 \\
(0.015)\end{array}$ & $\begin{array}{c}-0.104 \\
(0.015)\end{array}$ & $\begin{array}{r}-0.102 \\
(0.015)\end{array}$ \\
\hline 1984 & $\begin{array}{c}-0.133 \\
(0.015)\end{array}$ & $\begin{array}{c}-0.098 \\
(0.016)\end{array}$ & $\begin{array}{c}-0.106 \\
(0.015)\end{array}$ & $\begin{array}{r}-0.100 \\
(0.016)\end{array}$ & $\begin{array}{r}-0.100 \\
(0.016)\end{array}$ & $\begin{array}{r}-0.096 \\
(0.016)\end{array}$ \\
\hline 1985 & $\begin{array}{r}-0.156 \\
(0.016)\end{array}$ & $\begin{array}{c}-0.107 \\
(0.017)\end{array}$ & $\begin{array}{c}-0.111 \\
(0.017)\end{array}$ & $\begin{array}{c}-0.105 \\
(0.017)\end{array}$ & $\begin{array}{c}-0.107 \\
(0.018)\end{array}$ & $\begin{array}{r}-0.105 \\
(0.017)\end{array}$ \\
\hline 1986 & $\begin{array}{c}-0.126 \\
(0.016)\end{array}$ & $\begin{array}{c}-0.079 \\
(0.017)\end{array}$ & $\begin{array}{c}-0.082 \\
(0.017)\end{array}$ & $\begin{array}{c}-0.078 \\
(0.017)\end{array}$ & $\begin{array}{c}-0.081 \\
(0.017)\end{array}$ & $\begin{array}{r}-0.080 \\
(0.018)\end{array}$ \\
\hline 1987 & $\begin{array}{c}-0.132 \\
(0.018)\end{array}$ & $\begin{array}{c}-0.102 \\
(0.018)\end{array}$ & $\begin{array}{c}-0.099 \\
(0.018)\end{array}$ & $\begin{array}{c}-0.097 \\
(0.018)\end{array}$ & $\begin{array}{r}-0.092 \\
(0.019)\end{array}$ & $\begin{array}{r}-0.098 \\
(0.019)\end{array}$ \\
\hline 1988 & $\begin{array}{c}-0.153 \\
(0.017)\end{array}$ & $\begin{array}{c}-0.118 \\
(0.017)\end{array}$ & $\begin{array}{c}-0.111 \\
(0.017)\end{array}$ & $\begin{array}{c}-0.106 \\
(0.018)\end{array}$ & $\begin{array}{r}-0.102 \\
(0.018)\end{array}$ & $\begin{array}{r}-0.106 \\
(0.018)\end{array}$ \\
\hline 1989 & $\begin{array}{c}-0.160 \\
(0.017)\end{array}$ & $\begin{array}{c}-0.116 \\
(0.018)\end{array}$ & $\begin{array}{c}-0.127 \\
(0.018)\end{array}$ & $\begin{array}{c}-0.121 \\
(0.018)\end{array}$ & $\begin{array}{c}-0.121 \\
(0.018)\end{array}$ & $\begin{array}{r}-0.116 \\
(0.018)\end{array}$ \\
\hline 1990 & $\begin{array}{c}-0.136 \\
(0.018)\end{array}$ & $\begin{array}{c}-0.103 \\
(0.018)\end{array}$ & $\begin{array}{c}-0.114 \\
(0.018)\end{array}$ & $\begin{array}{c}-0.109 \\
(0.018)\end{array}$ & $\begin{array}{c}-0.108 \\
(0.019)\end{array}$ & $\begin{array}{c}-0.102 \\
(0.019)\end{array}$ \\
\hline 1991 & $\begin{array}{c}-0.139 \\
(0.017)\end{array}$ & $\begin{array}{c}-0.110 \\
(0.018)\end{array}$ & $\begin{array}{c}-0.100 \\
(0.018)\end{array}$ & $\begin{array}{c}-0.096 \\
(0.018)\end{array}$ & $\begin{array}{c}-0.101 \\
(0.018)\end{array}$ & $\begin{array}{c}-0.092 \\
(0.018)\end{array}$ \\
\hline 1992 & $\begin{array}{c}-0.155 \\
(0.018)\end{array}$ & $\begin{array}{c}-0.108 \\
(0.019)\end{array}$ & $\begin{array}{r}-0.118 \\
(0.019)\end{array}$ & $\begin{array}{c}-0.112 \\
(0.019)\end{array}$ & $\begin{array}{r}-0.111 \\
(0.019)\end{array}$ & $\begin{array}{r}-0.106 \\
(0.020)\end{array}$ \\
\hline 1993 & $\begin{array}{c}-0.143 \\
(0.019)\end{array}$ & $\begin{array}{c}-0.100 \\
(0.020)\end{array}$ & $\begin{array}{c}-0.106 \\
(0.020)\end{array}$ & $\begin{array}{c}-0.096 \\
(0.020)\end{array}$ & $\begin{array}{r}-0.098 \\
(0.021)\end{array}$ & $\begin{array}{r}-0.104 \\
(0.021)\end{array}$ \\
\hline 1994 & $\begin{array}{c}-0.051 \\
(0.020)\end{array}$ & $\begin{array}{c}-0.015 \\
(0.021)\end{array}$ & $\begin{array}{c}-0.010 \\
(0.021)\end{array}$ & $\begin{array}{c}-0.005 \\
(0.021)\end{array}$ & $\begin{array}{c}-0.004 \\
(0.022)\end{array}$ & $\begin{array}{r}-0.007 \\
(0.022)\end{array}$ \\
\hline 1995 & $\begin{array}{c}-0.135 \\
(0.022)\end{array}$ & $\begin{array}{r}-0.116 \\
(0.022)\end{array}$ & $\begin{array}{r}-0.100 \\
(0.023)\end{array}$ & $\begin{array}{c}-0.099 \\
(0.023)\end{array}$ & $\begin{array}{r}-0.090 \\
(0.023)\end{array}$ & $\begin{array}{r}-0.097 \\
(0.023)\end{array}$ \\
\hline 1996 & $\begin{array}{c}-0.120 \\
(0.022)\end{array}$ & $\begin{array}{c}-0.099 \\
(0.023)\end{array}$ & $\begin{array}{c}-0.091 \\
(0.023)\end{array}$ & $\begin{array}{c}-0.081 \\
(0.024)\end{array}$ & $\begin{array}{r}-0.080 \\
(0.024)\end{array}$ & $\begin{array}{r}-0.085 \\
(0.024)\end{array}$ \\
\hline 1997 & $\begin{array}{c}-0.173 \\
(0.024)\end{array}$ & $\begin{array}{c}-0.138 \\
(0.026)\end{array}$ & $\begin{array}{c}-0.139 \\
(0.026)\end{array}$ & $\begin{array}{c}-0.142 \\
(0.026)\end{array}$ & $\begin{array}{c}-0.134 \\
(0.027)\end{array}$ & $\begin{array}{c}-0.125 \\
(0.027)\end{array}$ \\
\hline
\end{tabular}

Coefficient estimates presented are for a single freerider dummy. Each column indicates the level of separate coverage dummies included in the model. Standard errors are in parentheses. Other right-hand side variables included are the same as those included in the regressions in Table 1. Occ, occupation; Ind, industry.

\section{Alternative Explanations for the Differential}

\section{Differences in Ability}

Other than the above explanation for the union freerider differential, it is important to examine alternative explanations for the differential. Estimates of union wage effects from Equation 2 are obtained assuming that all measures of human capital are included in the righthand side variables or that any omitted variables are uncorrelated with union status. The measured freerider penalty in the cross-sectional analysis is biased if unmeasured ability is correlated with union status. Wage change estimates of the freerider penalty as explained in Equation 4 
will be independent of any unmeasured ability and thus should be zero if unmeasured ability is what is driving the cross-sectional differential.

The CPS earnings supplement questions are asked of individuals in the same month for consecutive years (i.e., rotation group 4 in year $t$ and rotation group 8 in year $t+1$ ). In order to examine the issue of unmeasured ability, two-year panels for the year pairs 1983/1984 through 1994/1995 are constructed from the CPS. ${ }^{15}$ Because the census reinterviews households in fixed locations, individuals whose household moves or who move out of a household during the year are not represented in the sample. Young workers are most likely to be eliminated (Peracchi and Welch 1995; Card 1996). In order to minimize measurement error in the longitudinal sample, individuals for whom the census has allocated values of union status (in the 1989 or later surveys) or allocated earnings or with earnings at the cap are deleted from the sample.

Table 4 displays estimates of the coverage and membership effects under four alternative specifications of the model using two-year panels for the year pairs 1983/1984 to 1994/1995 and separate estimates for $1983 / 1984$ to $1988 / 1989$ and $1989 / 1990$ to $1994 / 1995$. Section 1 of Table 4 provides levels estimates using observations on the second year for each worker. The second section provides estimates of Equation 4. For each group, the freerider penalty estimate is substantially lower than levels estimates. For the pooled sample, the penalty falls from $-0.13 \log$ points to -0.06 $\log$ points. There are similar declines when examining the separate periods. These results suggest that about half of the cross-sectional freerider penalty is due to omitted factors and, once accounted for, there is a smaller wage advantage for membership. Also, once omitted variables are accounted for, there is only about a $7 \%$ differential associated with coverage.

A potential problem in longitudinal estimation of union wage effects, however, is measurement error in the data (Freeman 1984; Card 1996). Mismeasured union membership status lowers the signal-to-noise ratio in $\Delta$ Freerider, biasing the estimate of $\theta$ toward zero. Attempts were made to limit measurement error by omitting workers with allocated union status (for the 1989 to 1995 period only) or earnings (for most years). An additional way to control, in part, for measurement error on the change in union status variables is to distinguish between four types of union changers (Hirsch and Schumacher 1998): workers who change both (three-digit) occupation and industry as well as union status ( $\triangle \operatorname{Cov} \times$ Both and $\triangle F R E E \times B o t h)$, those who change industry but not occupation ( $\Delta \mathrm{Cov} \times$ Ind and $\Delta$ Free $\times$ Ind $)$, those who change occupation but not industry $(\triangle C o v \times O c c$ and $\triangle F r e e \times O c c)$, and those who change neither occupation nor industry $(\triangle \operatorname{Cov} \times$ None and $\triangle F R E E \times$ None $)$. The regressions also control for the change in occupation and industry in order to distinguish between wage effects associated with changes in union status and changes in sector of employment.

Section 3 of Table 4 displays these coefficient estimates. The coefficient estimates on $\Delta C o v$ $\times$ Both and $\Delta$ Free $\times$ Both are most likely to capture true union changes since these workers are most likely to be true union status changers. The coefficient on $\Delta \operatorname{Cov} \times$ Both is 0.17 , suggesting that a large part of the fall in the coverage coefficient in section 2 is due to measurement error and, once the four types of union changers are allowed, there is a much smaller difference between the levels and change estimates. The coefficients on the other $\Delta C o v$ variables are substantially smaller, consistent with a high degree of measurement error associated with

\footnotetext{
${ }^{15}$ Details on construction of the CPS panel are provided in Appendix 1. In 1989, the CPS began including a union status allocation flag. Prior to this change, individuals whose union status was assigned by the CPS were not distinguished from those who answered the questions. To reduce measurement error, individuals in the survey in 1989 and later who have union status allocated are omitted from the sample.
} 
Table 4. Levels Versus Change Estimates of Union Coverage and Freerider Wage Differentials

\begin{tabular}{|c|c|c|c|c|c|c|}
\hline & \multicolumn{2}{|c|}{ 1983/1984-1994/1995 } & \multicolumn{2}{|c|}{ 1983/1984-1988/1989 } & \multicolumn{2}{|c|}{ 1989/1990-1994/1995 } \\
\hline & Coefficient & $\begin{array}{l}\text { Standard } \\
\text { Error }\end{array}$ & Coefficient & $\begin{array}{l}\text { Standard } \\
\text { Error }\end{array}$ & Coefficient & $\begin{array}{l}\text { Standard } \\
\text { Error }\end{array}$ \\
\hline \multirow{2}{*}{$\begin{array}{l}\text { 1. Covered } \\
\text { Freerider }\end{array}$} & 0.224 & 0.004 & 0.243 & 0.006 & 0.198 & 0.006 \\
\hline & -0.125 & 0.010 & -0.125 & 0.014 & -0.120 & 0.015 \\
\hline \multirow{2}{*}{$\begin{array}{l}\text { 2. } \Delta \text { Covered } \\
\Delta \text { Freerider }\end{array}$} & 0.070 & 0.006 & 0.081 & 0.008 & 0.057 & 0.009 \\
\hline & -0.057 & 0.009 & -0.065 & 0.012 & -0.047 & 0.013 \\
\hline \multirow{8}{*}{ 3. $\begin{array}{l}\Delta \text { Cov } \times \text { Both } \\
\Delta \text { Cov } \times \text { Ind } \\
\Delta \text { Cov } \times \text { Occ } \\
\Delta \text { Cov } \times \text { None } \\
\Delta \text { Free } \times \text { Both } \\
\Delta \text { Free } \times \text { Ind } \\
\Delta \text { Free } \times \text { Occ } \\
\Delta \text { Free } \times \text { None }\end{array}$} & 0.166 & 0.012 & 0.187 & 0.016 & 0.139 & 0.019 \\
\hline & 0.072 & 0.020 & 0.084 & 0.027 & 0.058 & 0.031 \\
\hline & 0.045 & 0.011 & 0.057 & 0.015 & 0.031 & 0.016 \\
\hline & 0.035 & 0.009 & 0.037 & 0.012 & 0.032 & 0.013 \\
\hline & -0.083 & 0.021 & -0.080 & 0.029 & -0.079 & 0.031 \\
\hline & -0.057 & 0.030 & -0.066 & 0.040 & -0.047 & 0.044 \\
\hline & -0.045 & 0.016 & -0.064 & 0.021 & -0.021 & 0.024 \\
\hline & -0.046 & 0.013 & -0.045 & 0.018 & -0.047 & 0.020 \\
\hline \multirow{9}{*}{$\begin{array}{l}\text { 4. NU-Mem } \\
\text { NU-Freeride } \\
\text { Mem-NU } \\
\text { Mem-Mem } \\
\text { Mem-Freeride } \\
\text { Freeride-NU } \\
\text { Freeride-Mem } \\
\text { Freeride-Freeride } \\
\text { Sample Size }\end{array}$} & 0.068 & 0.009 & 0.076 & 0.012 & 0.060 & 0.013 \\
\hline & 0.014 & 0.012 & 0.030 & 0.016 & -0.003 & 0.017 \\
\hline & -0.072 & 0.008 & -0.088 & 0.011 & -0.052 & 0.013 \\
\hline & -0.018 & 0.004 & -0.017 & 0.006 & -0.020 & 0.007 \\
\hline & -0.056 & 0.027 & -0.054 & 0.034 & -0.059 & 0.042 \\
\hline & -0.013 & 0.011 & -0.001 & 0.015 & -0.026 & 0.017 \\
\hline & 0.054 & 0.024 & 0.059 & 0.032 & 0.048 & 0.037 \\
\hline & -0.004 & 0.017 & 0.010 & 0.023 & -0.019 & 0.025 \\
\hline & \multicolumn{2}{|c|}{127,554} & \multicolumn{2}{|c|}{63,948} & \multicolumn{2}{|c|}{63,606} \\
\hline
\end{tabular}

Data are from the 1983/1984-1994/1995 panels constructed from the CPS ORG files. The first two lines are from a levels equations using the data from the second year in the panel. The remaining lines are from a wage change equation using the change in log real wage as the dependent variable. $\Delta \operatorname{Cov} \times$ Both is equal to $1(-1)$ when an individual joins (leaves) a union and also changes both (three digit) occupation and industry, $\Delta \operatorname{Cov} \times \operatorname{Ind}$ is equal to $1(-1)$ when an individual joins (leaves) a union and changes industry but not occupation, $\Delta \operatorname{Cov} \times O c c$ is equal to $1(-1)$ when an individual joins (leaves) a union and changes occupation but not industry, and $\Delta \operatorname{Cov} \times$ None is equal to $1(-1)$ when an individual joins (leaves) a union and changes neither occupation or industry. $\Delta$ Free $\times$ Both, $\Delta$ Free $\times$ Ind, $\Delta$ Free $\times$ $O c c$, and $\Delta$ Free $\times$ None are defined similarly for covered nonmembers. The levels equations include the same righthand side variables as in Table 1. Other variables included in the change equations are the change in experience squared (interacted with gender), the change in part-time status, the change in marital status, the change in occupation (5), the change in industry (12), and year dummies (11). The regression in item 4 allows asymmetric effects. NU, nonunion; Mem, union member; Freeride, covered nonmember.

these individuals. There is a similar effect for the freerider penalty, although the difference in the wage level and wage change estimates is smaller than for the coverage differential. The coefficient on freeriders in the levels is -0.13 and, in the wage change specification, the coefficient on $\Delta$ Free $\times$ Both is -0.08 . There is a larger drop for the other $\Delta$ Free variables. A significant difference between the data prior to 1989 and that since 1989 (column 2 vs. column 3 ) is the availability of union status allocation flags in the later data. That there is a smaller difference between the levels and change estimates of the freerider penalty for the 1989/1990 $1994 / 1995$ sample is consistent with there being a greater proportion of measurement error among those with union status allocated. Thus, the results for 1989 forward may be the most reliable. These results suggest that, while omitted factors may play a small role in the freerider penalty, the results are sensitive to the presence of measurement error and there remains a rather substantial freerider penalty, even after controlling for worker-specific skills. ${ }^{16}$

${ }^{16}$ Note that the first differencing approach used here is dependent on the parameters being time independent. This was 
The final specification relaxes the symmetry restriction imposed in Equation 4 and allows separate coefficient estimates based on the direction of change. Controls are included for eight of the nine types of union changes (nonunion stayer is the omitted category). Individuals who move from nonunion to union member (NU-Mem) receive a wage gain of $0.068 \mathrm{log}$ points, while individuals moving from nonunion to freerider (NU-Freeride) receive an insignificant gain of $0.014 \mathrm{log}$ points. Individuals moving from freerider to member receive a $0.054 \mathrm{log}$ point wage gain (relative to freerider stayers), while those going from member to freerider (MemFreeride) receive a $-0.056 \log$ point wage loss (relative to member stayers).

\section{The Probationary Period of Initial Union Membership and Union Misclassification}

If workers are most likely to be covered nonmembers when they first enter a new job, part of the membership differential could be due to low job tenure for freeriders. While the CPS ORG data do not contain measures of job tenure, we test the hypothesis that the lower levels of job tenure among freeriders drives the membership differential by utilizing the longitudinal nature of the data. Using the two-year panels, we restrict our cross-sectional analysis to those who did not change union status between the two years since those who changed status are more likely to be in their probationary period. If the freerider penalty is reduced substantially utilizing this restricted sample, much of the membership premium is due to the probationary period effect.

Table 5 displays estimates of the coverage and membership differentials with and without restricting the sample. The top section of the table uses the entire sample and the results are identical to those presented in rows 1 and 2 of Table 4 . The lower section of the table restricts the sample to those who do not change union status between the two years of observation. Both specifications use data from the second year. The freerider penalty falls from -0.13 to -0.10 when restricting the sample to those who did not change status, suggesting that a nontrivial part of the membership differential could be driven by the lower tenure of covered nonmembers. Budd and Na (1997) examine the January 1987 CPS supplement, however, which reports tenure with the current employer, and find little evidence that tenure differences drive the membership differential. Estimates of the membership differential are unaffected by inclusion of tenure in log-wage regressions.

An alternative interpretation of the reduction in the freerider penalty when restricting the sample to nonchangers is that the freerider penalty is driven by response error. The results presented in the restricted regressions only classify individuals as covered nonmembers if they reported the same status in consecutive years and thus individuals are less likely to be miscoded. The difference between the restricted and the unrestricted sample is larger for the years prior to 1989, again consistent with there being more measurement error in the data for the earlier period. Thus, consistent with the conclusions of Jones (1982), union status misclassification

\footnotetext{
shown in section 3 not to hold true for the entire sample. If there have been structural changes between the year-pairs used in the first differencing, then resulting coefficient estimates may be biased (Baltagi 1995). In Table 4, I display separate estimates splitting the sample into two periods where this is less likely to be a problem and obtain very similar results. Further dividing the sample into six groups (1983/1984-1984/1985, 1985/1986-1986/1987, 1987/1988-1988/ $1989,1989 / 1990-1990 / 1991,1991 / 1992-1992 / 1993$, and 1993/1994-1994/1995) results in relatively small sample sizes of union changers but yields very similar results to those presented in Table 4. Coefficient estimates on the change in freerider status range from about -0.05 to about -0.12 .
} 
Table 5. Evidence on the Probationary Period Effect and Misclassification

\begin{tabular}{lccc}
\hline & $1983 / 1984-1994 / 1995$ & $1983 / 1984-1988 / 1989$ & $1989 / 1990-1994 / 1995$ \\
\hline Unrestricted & & & \\
Covered & 0.224 & 0.243 & 0.198 \\
& $(0.004)$ & $(0.006)$ & $(0.006)$ \\
Freerider & -0.125 & -0.125 & -0.120 \\
& $(0.010)$ & $(0.014)$ & $(0.015)$ \\
Sample Size & 127,554 & 63,948 & 63,606 \\
Restricted & & & \\
Covered & 0.258 & 0.272 & 0.236 \\
& $(0.005)$ & $(0.006)$ & $(0.007)$ \\
Freerider & -0.098 & -0.080 & -0.114 \\
& $(0.018)$ & $(0.024)$ & $(0.027)$ \\
Sample Size & 120,893 & 60,378 & 60,515 \\
\hline
\end{tabular}

Data are from the 1983/1994-1994/1995 panels constructed from the CPS ORG files. Standard errors in parentheses. Both the unrestricted and restricted models are levels equations using the second year of the panel with the log real wage as the dependent variable. The restricted model restricts the sample to those individuals who did not change union status between the two years. Other variables included in these regressions are potential experience and its square (interacted with gender), years of schooling, dummies for MSA size, gender, race (3), Hispanic status, marital status (2), part-time status, region (4), industry (12), occupation (5), and year (11).

could be explaining a small part of the freerider penalty. A rather substantial penalty remains, however. ${ }^{17}$

\section{Conclusions}

This paper examines the union membership wage advantage relative to covered nonmembers. The results show that estimates of the impact of unions on wages (over noncovered workers) are not seriously affected by the use of either membership or coverage, consistent with the conclusion of Lewis (1986). There exists, however, a rather large wage penalty for union freeriders. Cross-sectional estimates suggest that covered nonmembers earn about $13 \%$ lower wages than union members. Efforts to explain the source of the differential find little support for the hypotheses that it is accounted for by higher unmeasured ability among members than freeriders, lower job tenure of newly hired covered nonmembers, a higher degree of misclassification among covered nonmembers, differences in overtime pay, or industry and occupational wage effects.

There appears to be a correlation between the union/nonunion wage and freerider status. When there are few freeriders in a particular occupation/industry sector, the union/nonunion wage differential tends to be large. Alternatively, when there are many freeriders in the sector, the coverage differential is small and there is little difference in earnings between members and

\footnotetext{
${ }^{17}$ I also examined whether the union membership wage differential might be driven in part by a higher incidence of overtime work for union members or by differences in industry or occupation effects. For example, if unionized foremen give members the first chance at overtime work, their effective hourly wage will be higher than covered nonmembers (since the implied wage used in the analysis included tips, overtime, and commissions). Alternatively, if freeriders are concentrated in occupations or industries with low wages, this could explain the differential. In this case, the differential is attributed to occupation or industry wage differentials and not due directly to membership. I find no evidence, however, that either of these explanations accounts for any of the freerider penalty.
} 
freeriders. The freerider penalty is reduced significantly when allowing the coverage coefficient to vary by industry and occupation group. Since unions are required to equally represent covered employees regardless of their membership status, a union member will earn the same wage as an equivalent nonmember covered by the same collective bargaining agreement. Reilly's (1996) establishment level study finds no evidence of a freerider differential, suggesting freerider status must be capturing something other than freeriding per se. Together, these results suggest that the data are picking up wage effects across contract coverage units and freeriders are clustered in covered jobs where the union power is small.

What I have not been able to determine, however, is the direction of causation between freeriders and union wages. The high union wage differential may be encouraging membership since the gains for joining are large. In this case, when a union is able to obtain a favorable contract for its covered employees in terms of both wages and nonwage benefits, individuals are more likely to join. When there are few benefits from union representation, workers are less likely to become members. Alternatively, the causation may be in the other direction. If freeriders erode union strength, then freeriding causes the lower coverage wage differential.

A recent events study by Abraham and Voos (1997) provides some insight into this issue. They examine the change in the value of corporations in Idaho after right-to-work laws were adopted in 1985 and in Louisiana after a right-to-work law was passed in 1976. They find that stockholder wealth rose significantly after the adoption of the laws, suggesting that right-towork laws have a real effect. They argue this occurred because investors anticipated higher future profits with weaker labor unions and/or a lower probability of future organization. These findings are consistent with the findings here and imply that freeriding erodes the strength of the union and freeriding causes the lower union wage differential.

The direction of causation is important for policy implications. If freeriding causes weaker unions, RTW laws will be detrimental to union organizing and bargaining power. If, however, the low bargaining power and a small premium results in a higher proportion of freeriders, RTW laws will have a much smaller impact. I suspect causality runs in both directions. While this paper has not been able to measure the relative contribution of each, it has identified an important relationship between freeriding and union strength.

\section{Appendix 1: Construction of the Cross-Sectional and Longitudinal Data Sets}

\section{The CPS ORG Data}

The cross-sectional data for this paper are drawn from the monthly Current Population Surveys (CPS) conducted by the Bureau of the Census. Households are included in the CPS for eight monthly surveys (or eight rotation groups) comprising four months in, eight months out, and then four months in. Beginning in 1979, only the outgoing rotation groups (ORG) 4 and 8 (a quarter sample) were asked the earnings supplement questions (earnings, hours worked, union status, etc.), but these questions were asked in every monthly survey. Union status was not asked in each month until 1983. Thus, the merged CPS ORG files contain data for all 12 monthly surveys in each year for 1983-1996 and through October for 1997. The CPS contains personal, occupational, and regional information on individuals in and out of the labor force. The 1983-1997 CPS ORG earnings files are not public use tapes but are made available through the research and data services staff at the Bureau of Labor Statistics.

\section{Construction of Longitudinal Samples from the CPS ORG Files}

Outgoing rotation groups 4 and 8 are asked earnings supplement questions (weekly earnings, hours, union status, etc.). The CPS contains household identification numbers (ID) and record line numbers but not individual identifiers. Individuals potentially can be identified for the same month in consecutive years; that is, individuals in rotation 4 in year 1 can be matched to individuals in rotation 8 in year 2 . 
The longitudinal ORG file was created in the following manner. Separate data files were created for males and females and for pairs of years (rotation $4 / 1983$ and rotation $8 / 1984$, rotation $4 / 1984$ and rotation $8 / 1985$, etc.). Within each file, individuals were sorted as appropriate on the basis of ascending and descending household ID, year, and age. To be considered an acceptable matched pair, a rotation 8 individual had to be matched with a rotation 4 individual with identical household ID, identical survey month, and an age difference between zero and two (since surveys can occur on different days of the month, age change need not equal one). Several passes were necessary because a single household may contain more than one male or female pair. Checks were provided to insure that only unique matches were selected. For each rotation 8 individual, the search was made through all rotation 4 individuals with the same ID to make sure there was only one possible match; the file was resorted in reverse order and each selected rotation 4 individual was checked to insure a unique rotation 8 match. As uniquely matched pairs were identified, they were removed from the work file. Incorrect changes in the variables marital status, veteran status, race, and education (e.g., a change in schooling other than zero or one, a change from married to never married, etc.) were used to delete "bad" observations in households were there were multiple observations and ages too close to separate matched pairs. Several passes at the data were made. In households where two pairs of individuals could be separated based on a one-year but not the zero to two-year age change, a one-year criterion was used. If a unique pair could not be identified based on these criteria, they were not included in the data set (e.g., four observations with two identical pairs or three individuals with two possible matches using the zero to two age change criterion).

There are several reasons why matches cannot be made or that individual worker pairs are not included in the CPS ORG panel. The principal reasons are a household move (thus changing the household ID), an individual moving out of a household, a worker becoming self-employed, an individual dropping out of the labor market or failing to meet other sample selection criteria, or the Census Bureau being unable to reinterview a household and/or receive information on the individual. Inclusion rates for the entire CPS ORG panel are just under two thirds of employed wage and salary workers in any year. Peracchi and Welch (1995) analyze attrition rates among matched March CPS files and conclude that age is the most important determinant of a successful match. Other factors that lessen match probabilities are poor health, low schooling, and not a household head, while sex and race are unimportant match predictors following control for other factors. Finally, sample sizes are reduced further to roughly half the normal size for the 1984/1985 panel and to one quarter for $1985 / 1986$. This is the result of a CPS test sample from July-September 1985 that implemented new population weights. Rotation 4 households interviewed in July 1984 through September 1985 were not reinterviewed a year later in 1985 and 1986.

\section{Appendix 2}

Variable Means and OLS Regression Results

\begin{tabular}{|c|c|c|c|c|c|c|}
\hline & \multicolumn{2}{|c|}{ All } & \multicolumn{2}{|c|}{ White Collar } & \multicolumn{2}{|c|}{ Blue Collar } \\
\hline & Mean & Coeff. & Mean & Coeff. & Mean & Coeff. \\
\hline Union Coverage & 0.071 & $\begin{array}{c}0.240 \\
(0.002)\end{array}$ & 0.032 & $\begin{array}{c}0.188 \\
(0.004)\end{array}$ & 0.141 & $\begin{array}{c}0.269 \\
(0.002)\end{array}$ \\
\hline Union Freerider & 0.013 & $\begin{array}{c}-0.140 \\
(0.005)\end{array}$ & 0.011 & $\begin{array}{c}-0.120 \\
(0.007)\end{array}$ & 0.017 & $\begin{array}{r}-0.129 \\
(0.006)\end{array}$ \\
\hline Female Experience & 8.638 & $\begin{array}{c}0.014 \\
(0.000)\end{array}$ & 11.100 & $\begin{array}{c}0.015 \\
(0.000)\end{array}$ & 4.2112 & $\begin{array}{c}0.011 \\
(0.000)\end{array}$ \\
\hline Female Experience $2 / 100$ & 2.392 & $\begin{array}{c}-0.024 \\
(0.000)\end{array}$ & 3.065 & $\begin{array}{c}-0.025 \\
(0.000)\end{array}$ & 1.182 & $\begin{array}{r}-0.012 \\
(0.001)\end{array}$ \\
\hline Male Experience & 9.699 & $\begin{array}{c}0.028 \\
(0.000)\end{array}$ & 7.035 & $\begin{array}{c}0.032 \\
(0.000)\end{array}$ & 14.494 & $\begin{array}{c}0.023 \\
(0.001)\end{array}$ \\
\hline Male Experience $2 / 100$ & 2.620 & $\begin{array}{c}-0.047 \\
(0.000)\end{array}$ & 1.919 & $\begin{array}{c}-0.055 \\
(0.001)\end{array}$ & 3.883 & $\begin{array}{r}-0.038 \\
(0.000)\end{array}$ \\
\hline Schooling & 12.658 & $\begin{array}{c}0.048 \\
(0.000)\end{array}$ & 13.297 & $\begin{array}{c}0.056 \\
(0.000)\end{array}$ & 11.507 & $\begin{array}{c}0.034 \\
(0.000)\end{array}$ \\
\hline Female & 0.468 & $\begin{array}{c}-0.090 \\
(0.002)\end{array}$ & 0.613 & $\begin{array}{c}-0.062 \\
(0.003)\end{array}$ & 0.208 & $\begin{array}{r}-0.087 \\
(0.005)\end{array}$ \\
\hline Black & 0.117 & $\begin{array}{c}-0.114 \\
(0.002)\end{array}$ & 0.097 & $\begin{array}{c}-0.103 \\
(0.002)\end{array}$ & 0.152 & $\begin{array}{r}-0.120 \\
(0.002)\end{array}$ \\
\hline
\end{tabular}


Variable Means and OLS Regression Results (Continued)

\begin{tabular}{|c|c|c|c|c|c|c|}
\hline & \multicolumn{2}{|c|}{ All } & \multicolumn{2}{|c|}{ White Collar } & \multicolumn{2}{|c|}{ Blue Collar } \\
\hline & Mean & Coeff. & Mean & Coeff. & Mean & Coeff. \\
\hline Other & 0.012 & $\begin{array}{c}-0.067 \\
(0.004)\end{array}$ & 0.010 & $\begin{array}{c}-0.061 \\
(0.006)\end{array}$ & 0.014 & $\begin{array}{c}-0.074 \\
(0.006)\end{array}$ \\
\hline Asian & 0.008 & $\begin{array}{c}-0.063 \\
(0.005)\end{array}$ & 0.009 & $\begin{array}{c}-0.039 \\
(0.007)\end{array}$ & 0.006 & $\begin{array}{r}-0.133 \\
(0.009)\end{array}$ \\
\hline Hispanic & 0.069 & $\begin{array}{l}-0.103 \\
(0.002)\end{array}$ & 0.058 & $\begin{array}{c}-0.092 \\
(0.003)\end{array}$ & 0.087 & $\begin{array}{r}-0.129 \\
(0.003)\end{array}$ \\
\hline Married, Spouse Present & 0.617 & $\begin{array}{c}0.090 \\
(0.001)\end{array}$ & 0.611 & $\begin{array}{c}0.083 \\
(0.002)\end{array}$ & 0.628 & $\begin{array}{c}0.103 \\
(0.002)\end{array}$ \\
\hline $\begin{array}{l}\text { Divorced, Separated, } \\
\text { or Widowed }\end{array}$ & 0.162 & $\begin{array}{c}0.051 \\
(0.002)\end{array}$ & 0.170 & $\begin{array}{c}0.050 \\
(0.002)\end{array}$ & 0.149 & $\begin{array}{c}0.055 \\
(0.003)\end{array}$ \\
\hline Part-Time & 0.156 & $\begin{array}{c}-0.141 \\
(0.001)\end{array}$ & 0.198 & $\begin{array}{c}-0.131 \\
(0.002)\end{array}$ & 0.079 & $\begin{array}{c}-0.165 \\
(0.003)\end{array}$ \\
\hline South Atlantic & 0.362 & $\begin{array}{c}0.033 \\
(0.001)\end{array}$ & 0.359 & $\begin{array}{c}0.039 \\
(0.002)\end{array}$ & 0.367 & $\begin{array}{c}0.014 \\
(0.002)\end{array}$ \\
\hline East South Central & 0.106 & $\begin{array}{c}-0.022 \\
(0.002)\end{array}$ & 0.093 & $\begin{array}{c}-0.006 \\
(0.003)\end{array}$ & 0.128 & $\begin{array}{c}-0.055 \\
(0.003)\end{array}$ \\
\hline West South Central & 0.199 & $\begin{array}{c}0.015 \\
(0.002)\end{array}$ & 0.202 & $\begin{array}{c}0.022 \\
(0.002)\end{array}$ & 0.192 & $\begin{array}{c}-0.001 \\
(0.003)\end{array}$ \\
\hline Mountain & 0.155 & $\begin{array}{c}0.070 \\
(0.002)\end{array}$ & 0.161 & $\begin{array}{c}0.064 \\
(0.002)\end{array}$ & 0.145 & $\begin{array}{c}0.084 \\
(0.003)\end{array}$ \\
\hline 1984 & 0.066 & $\begin{array}{c}-0.005 \\
(0.003)\end{array}$ & 0.063 & $\begin{array}{c}-0.001 \\
(0.004)\end{array}$ & 0.073 & $\begin{array}{c}-0.012 \\
(0.004)\end{array}$ \\
\hline 1985 & 0.068 & $\begin{array}{c}0.003 \\
(0.003)\end{array}$ & 0.066 & $\begin{array}{c}0.007 \\
(0.004)\end{array}$ & 0.072 & $\begin{array}{c}-0.003 \\
(0.005)\end{array}$ \\
\hline 1986 & 0.068 & $\begin{array}{c}-0.010 \\
(0.005)\end{array}$ & 0.067 & $\begin{array}{c}-0.011 \\
(0.006)\end{array}$ & 0.076 & $\begin{array}{c}-0.004 \\
(0.007)\end{array}$ \\
\hline 1987 & 0.069 & $\begin{array}{c}-0.019 \\
(0.005)\end{array}$ & 0.068 & $\begin{array}{c}-0.018 \\
(0.006)\end{array}$ & 0.072 & $\begin{array}{r}-0.019 \\
(0.007)\end{array}$ \\
\hline 1988 & 0.071 & $\begin{array}{c}-0.031 \\
(0.005)\end{array}$ & 0.070 & $\begin{array}{c}-0.030 \\
(0.006)\end{array}$ & 0.073 & $\begin{array}{c}-0.030 \\
(0.007)\end{array}$ \\
\hline 1989 & 0.072 & $\begin{array}{c}-0.017 \\
(0.005)\end{array}$ & 0.071 & $\begin{array}{c}-0.010 \\
(0.006)\end{array}$ & 0.074 & $\begin{array}{c}-0.024 \\
(0.007)\end{array}$ \\
\hline 1990 & 0.072 & $\begin{array}{c}-0.027 \\
(0.005)\end{array}$ & 0.072 & $\begin{array}{c}-0.016 \\
(0.006)\end{array}$ & 0.073 & $\begin{array}{c}-0.043 \\
(0.007)\end{array}$ \\
\hline 1991 & 0.071 & $\begin{array}{c}-0.032 \\
(0.005)\end{array}$ & 0.070 & $\begin{array}{c}-0.017 \\
(0.006)\end{array}$ & 0.070 & $\begin{array}{c}-0.052 \\
(0.007)\end{array}$ \\
\hline 1992 & 0.070 & $\begin{array}{c}-0.038 \\
(0.005)\end{array}$ & 0.071 & $\begin{array}{c}-0.018 \\
(0.006)\end{array}$ & 0.068 & $\begin{array}{c}-0.067 \\
(0.007)\end{array}$ \\
\hline 1993 & 0.069 & $\begin{array}{c}-0.018 \\
(0.005)\end{array}$ & 0.070 & $\begin{array}{c}-0.016 \\
(0.006)\end{array}$ & 0.067 & $\begin{array}{r}-0.077 \\
(0.007)\end{array}$ \\
\hline 1994 & 0.065 & $\begin{array}{c}-0.034 \\
(0.005)\end{array}$ & 0.067 & $\begin{array}{c}-0.025 \\
(0.006)\end{array}$ & 0.060 & $\begin{array}{c}-0.058 \\
(0.007)\end{array}$ \\
\hline 1995 & 0.065 & $\begin{array}{c}0.018 \\
(0.005)\end{array}$ & 0.068 & $\begin{array}{c}0.045 \\
(0.006)\end{array}$ & 0.060 & $\begin{array}{r}-0.026 \\
(0.007)\end{array}$ \\
\hline 1996 & 0.059 & $\begin{array}{c}-0.045 \\
(0.005)\end{array}$ & 0.062 & $\begin{array}{c}-0.034 \\
(0.006)\end{array}$ & 0.053 & $\begin{array}{c}-0.058 \\
(0.007)\end{array}$ \\
\hline 1997 & 0.050 & $\begin{array}{c}-0.033 \\
(0.005)\end{array}$ & 0.052 & $\begin{array}{c}-0.017 \\
(0.006)\end{array}$ & 0.045 & $\begin{array}{l}-0.055 \\
(0.007)\end{array}$ \\
\hline $\begin{array}{l}\text { MSA (January 1983- } \\
\text { June 1985) }\end{array}$ & 0.020 & $\begin{array}{c}0.126 \\
(0.004)\end{array}$ & 0.022 & $\begin{array}{c}0.032 \\
(0.005)\end{array}$ & 0.016 & $\begin{array}{l}0.115 \\
(0.006)\end{array}$ \\
\hline
\end{tabular}


Variable Means and OLS Regression Results (Continued)

\begin{tabular}{|c|c|c|c|c|c|c|}
\hline & \multicolumn{2}{|c|}{ All } & \multicolumn{2}{|c|}{ White Collar } & \multicolumn{2}{|c|}{ Blue Collar } \\
\hline & Mean & Coeff. & Mean & Coeff. & Mean & Coeff. \\
\hline $\begin{array}{l}\text { Non MSA (October 1985- } \\
\text { October 1997) }\end{array}$ & 0.317 & $\begin{array}{c}-0.049 \\
(0.004)\end{array}$ & 0.280 & $\begin{array}{c}-0.053 \\
(0.005)\end{array}$ & 0.383 & $\begin{array}{c}-0.041 \\
(0.006)\end{array}$ \\
\hline $\begin{array}{l}\text { MSA Size } 1 \text { (October 1985- } \\
\text { October 1997) }\end{array}$ & 0.076 & $\begin{array}{c}-0.002 \\
(0.004)\end{array}$ & 0.079 & $\begin{array}{c}0.004 \\
(0.006)\end{array}$ & 0.072 & $\begin{array}{r}-0.009 \\
(0.007)\end{array}$ \\
\hline $\begin{array}{l}\text { MSA Size } 2 \text { (October 1985- } \\
\text { October 1997) }\end{array}$ & 0.066 & $\begin{array}{c}0.024 \\
(0.004)\end{array}$ & 0.069 & $\begin{array}{c}0.023 \\
(0.006)\end{array}$ & 0.061 & $\begin{array}{c}0.018 \\
(0.007)\end{array}$ \\
\hline $\begin{array}{l}\text { MSA Size } 3 \text { (October 1985- } \\
\text { October 1997) }\end{array}$ & 0.121 & $\begin{array}{c}0.074 \\
(0.004)\end{array}$ & 0.133 & $\begin{array}{c}0.084 \\
(0.006)\end{array}$ & 0.098 & $\begin{array}{c}0.052 \\
(0.006)\end{array}$ \\
\hline $\begin{array}{l}\text { MSA Size } 4 \text { (October 1985- } \\
\text { October 1997) }\end{array}$ & 0.115 & $\begin{array}{c}0.060 \\
(0.004)\end{array}$ & 0.127 & $\begin{array}{c}0.071 \\
(0.006)\end{array}$ & 0.095 & $\begin{array}{c}0.036 \\
(0.006)\end{array}$ \\
\hline $\begin{array}{l}\text { MSA Size } 5 \text { (October 1985- } \\
\text { October 1997) }\end{array}$ & 0.082 & $\begin{array}{c}0.145 \\
(0.004)\end{array}$ & 0.095 & $\begin{array}{c}0.158 \\
(0.006)\end{array}$ & 0.060 & $\begin{array}{c}0.106 \\
(0.007)\end{array}$ \\
\hline $\begin{array}{l}\text { MSA Size } 6 \text { (October 1985- } \\
\text { October 1997) }\end{array}$ & 0.001 & $\begin{array}{c}0.214 \\
(0.013)\end{array}$ & 0.002 & $\begin{array}{c}0.224 \\
(0.016)\end{array}$ & 0.001 & $\begin{array}{c}0.135 \\
(0.029)\end{array}$ \\
\hline $\begin{array}{l}\text { Missing MSA (July 1985- } \\
\text { September 1985, June 1995- } \\
\text { December 1995) }\end{array}$ & 0.055 & $\begin{array}{c}-0.019 \\
(0.004)\end{array}$ & 0.056 & $\begin{array}{c}-0.020 \\
(0.005)\end{array}$ & 0.053 & $\begin{array}{r}-0.018 \\
(0.006)\end{array}$ \\
\hline Industry Classification (12) & & Yes & & Yes & & Yes \\
\hline $\begin{array}{l}\text { Occupational } \\
\text { Classification (6) }\end{array}$ & & Yes & & Yes & & Yes \\
\hline Sample Size & \multicolumn{2}{|c|}{694,304} & \multicolumn{2}{|c|}{446,288} & \multicolumn{2}{|c|}{248,016} \\
\hline
\end{tabular}

Standard errors in parentheses.

\section{References}

Abraham, Steven E., and Paula B. Voos. 1997. Right-to-work laws: New evidence from the stock market. Working Paper, Industrial Relations Research Institute, University of Wisconsin.

Baltagi, Badi H. 1995. Econometric analysis of panel data. New York: John Wiley and Sons.

Blakemore, Arthur E., Janet C. Hunt, and B. F. Kiker. 1986. Collective bargaining and union membership effects on the wages of male youths. Journal of Labor Economics 4:193-211.

Blanchflower, David. 1997. Changes over time in union relative wage effects in Great Britain and the United States. NBER Working Paper No. 6100.

Booth, Alison L. 1985. The free rider problem and a social custom model of trade union membership. Quarterly Journal of Economics 100:253-61.

Budd, John W., and In-Gang Na. 1997. The union membership wage premium for employees covered by collective bargaining agreements. Working Paper, Industrial Relations Center, University of Minnesota.

Card, David. 1996. The effect of unions on the structure of wages: A longitudinal analysis. Econometrica 64:957-79.

Chaison, Gary N., and Dileep G. Dhavale. 1992. The choice between union membership and freerider status. Journal of Labor Research XIII:355-69.

Christensen, Sandra, and Dennis Maki. 1983. The wage effect of compulsory union membership. Industrial and Labor Relations Review 36:230-8.

Davis, Joe C., and John H. Huston. 1993. Right-to-work laws and free riding. Economic Inquiry 31:52-8.

Dickens, William T., and B. A. Ross. 1984. Consistent estimation using data from more than one sample. NBER Technical Working Paper No. 33.

Duncan, Gregory M., and Duane E. Leigh. 1980. Wage determination in the union and nonunion sectors: A sample selectivity approach. Industrial and Labor Relations Review 34:24-34.

Ellwood, David T., and Glenn Fine. 1987. The impact of right-to-work laws on union organizing. Journal of Political Economy 95:250-73.

Farber, Henry S. 1984. Right-to-work laws and the extent of unionism. Journal of Labor Economics 2:319-52.

Freeman, Richard B. 1984. Longitudinal analyses of the effects of trade unions. Journal of Labor Economics 2:1-26. 
Hirsch, Barry T., and John T. Addison. 1986. The economic analysis of unions: New approaches and evidence. Boston: Allen and Unwin.

Hirsch, Barry T., and David A. Macpherson. 1997. Union membership and earnings data book: Compilations from the Current Population Survey. 1997 edition. Washington, DC: Bureau of National Affairs.

Hirsch, Barry T., and Edward J. Schumacher. 1998. Unions, wages, and skills. Journal of Human Resources 33:201-19.

Hundley, Gregg. 1993. Collective bargaining coverage of union members and nonmembers in the public sector. Industrial Relations 32:72-93.

Hunt, Janet C., B. F. Kiker, and C. Glyn Williams. 1987. The effect of union type on member-nonmember wage differentials. Journal of Labor Research 8:59-65.

Jakubson, George. 1991. Estimation and testing of the union wage effect using panel data. Review of Economic Studies 58:971-91.

Jones, Ethel B. 1982. Union/nonunion differentials: Membership or coverage? The Journal of Human Resources 17: 276-85.

Lee, Lung-Fei. 1978. Unionism and wage rates: A simultaneous equations model with qualitative and limited dependent variables. International Economic Review 19:415-32.

Lewis, H. Gregg. 1986. Union relative wage effects: A survey. Chicago: University of Chicago Press.

Moore, William J. 1998. The determinants and effects of right-to-work laws: A review of the recent literature. Journal of Labor Research XIX:445-69.

Moore, William J., and Robert J. Newman. 1985. The effects of right-to-work laws: A review of the literature. Industrial and Labor Relations Review 38:571-85.

Naylor, Robin. 1989. Strikes, free riders and social customs. Quarterly Journal of Economics 104:771-85.

Naylor, Robin, and M. Cripps. 1993. An economic theory of the open shop trade union. European Economic Review 37:1599-620

Peracchi, Franco, and Finis Welch. 1995. How representative are matched cross sections? Evidence from the Current Population Survey. Journal of Econometrics 68:153-79.

Reilly, Kevin T. 1996. Does union membership matter? The effect of establishment union density on the union wage differential. The Review of Economics and Statistics 78:547-57.

Robinson, Chris. 1989a. Union endogeneity and self-selection. Journal of Labor Economics 7:106-12.

Robinson, Chris. 1989b. The joint determination of union status and union wage effects: Some tests of alternative models. Journal of Political Economy 97:639-67.

Sobel, Russell S. 1995. Empirical evidence on the union freerider problem: Do right-to-work laws matter? Journal of Labor Research XVI:347-65.

Weil, David. 1997. Analyzing regulatory performance: Insights on implementation of federal workplace policy. In Government regulation of the employment relationship, edited by Bruce E. Kaufman. Madison, WI: Industrial Relations Research Association. 